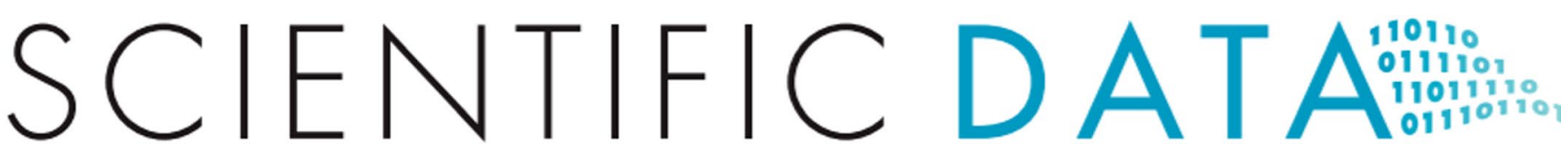

Check for updates

OPEN

\section{Publisher Correction: Large-scale} metabolic interaction network of the mouse and human gut microbiota

\section{Roktaek Lim D, Josephine Jill T. Cabatbat, Thomas L. P. Martin, Haneul Kim, Seunghyeon Kim, Jaeyun Sung, Cheol-Min Ghim \& Pan-Jun Kim (1)}

Correction to: Scientific Data https://doi.org/10.1038/s41597-020-0516-5, published online 26 June 2020

Following publication of this Data Descriptor, a number of errors were noted in the manuscript text, Table 1, Online-only Table 5 and Supplementary Table 1 in relation to a formatting change made to Supplementary Table 1.

Erroneous linkage to Figures 2 and 3 in the Figure 3 legend have been removed.

In addition, Figure 1 has been replaced to include an additional motif that had been excluded at publication.

These errors have been corrected in both the HTML and PDF versions of this Data Descriptor.

(c) (i) Open Access This article is licensed under a Creative Commons Attribution 4.0 International License, which permits use, sharing, adaptation, distribution and reproduction in any medium or format, as long as you give appropriate credit to the original author(s) and the source, provide a link to the Creative Commons license, and indicate if changes were made. The images or other third party material in this article are included in the article's Creative Commons license, unless indicated otherwise in a credit line to the material. If material is not included in the article's Creative Commons license and your intended use is not permitted by statutory regulation or exceeds the permitted use, you will need to obtain permission directly from the copyright holder. To view a copy of this license, visit http://creativecommons.org/licenses/by/4.0/.

(c) The Author(s) 2020 